\title{
The Impact of Institution Factors on Commercial Banks' Risk in China
}

\author{
Peng Zhou \\ School of Economics, Jinan University, Guangzhou, China \\ Email: nationwide@163.com
}

How to cite this paper: Zhou, P. (2018) The Impact of Institution Factors on Commercial Banks' Risk in China. Journal of Financial Risk Management, 7, 157-173. https://doi.org/10.4236/jfrm.2018.72011

Received: May 8, 2018

Accepted: June 19, 2018

Published: June 22, 2018

Copyright (C) 2018 by author and Scientific Research Publishing Inc. This work is licensed under the Creative Commons Attribution International License (CC BY 4.0).

http://creativecommons.org/licenses/by/4.0/

\begin{abstract}
In this paper, the institutional environment is included in the study of the risk of commercial banks, and the impact mechanism of the risk of commercial banks under the background of system reform is discussed. This paper constructs a theoretical model of institutional factors on the risk of commercial banks, and discusses the possibility of the impact of the institutional environment on the bank risk, and constructs a non-balanced panel regression model by selecting the variables that reflect the unsystematic risk and systemic risk of the bank, and carries on the empirical analysis.
\end{abstract}

\section{Keywords}

Institutional Factors, Unsystematic risk, Systemic Risk

\section{Introduction}

China's commercial banks are in a constantly changing institutional environment. The eighteenth National Party anti-corruption work has entered a fast track. The construction of the legal system is also effective. It paved the way for anti-corruption. The road has also effectively cooperated with the market-oriented reform in the new stage. The great changes in the system level will certainly make the commercial banks as the main economic body affected. The risk of commercial banks has always been the focus of concern.

This paper aims to study the influence mechanism of institutional factors on bank risk, and establish the theoretical model of institutional factors on the impact of bank risks, and then analyze the impact of institutional environment factors on risk. The paper not only expands the related theories of risk factors, but also supplements the institutional economics.

This paper is limited to the lack of data from emerging network banks and 
foreign commercial banks. Incorporating these banks into the research system can better reflect the impact mechanism of institutional and industrial factors on bank risks.

The article is organized as follows. Section 2 is a literature review, which illustrates the domestic and foreign research on the factors of bank risk; Section 3 establishes the theoretical model of institutional factors on the impact of bank risks; Section 4 presents the design of research, such as data sources, model, hypothesis, and variable definition; Section 5 presents the empirical results; Section 6 makes main conclusions and some advices.

\section{Literature Review}

\subsection{Institutional Factors on Bank Risk}

Merton (1977) first introduced the deposit insurance system to the risk of commercial banks, and considered that the deposit insurance system is one of the main factors that cause the bank risk to increase. Early domestic literature research, such as Li \& Han (2008), found that implicit insurance reduced the sensitivity of franchise value to bank risk-taking. With the effective promotion of China's interest rate marketization, the domestic literature re examines the impact of explicit deposit insurance system on the risk taking of commercial banks. Bao \& Shi (2016), based on the empirical results of 2006-2013's transnational panel data, show that the explicit deposit insurance system will improve the systemic risk level. However, Zhang \& Sun (2016) choose 71 countries from 2000 to 2013 to find that the reasonable deposit insurance system design can improve the financial system, safety, effective bank risk taking behavior.

Jokipii (2011) and Shim (2010) think that capital adequacy ratio regulation has increased the risk bearing level of banks. Guo \& Li (2014), based on the data of 44 commercial banks in China for 2000-2012 years, found whether monetary policy and regulatory policy can play a role in reducing the risk of commercial banks. The key depends on the low or high level of the bank's profitability. Other studies believe that there is a nonlinear relationship between capital regulation and risk taking of commercial banks.

Wang \& Wang (2016), based on provincial panel data and GMM method, found that the degree of government corruption is positively related to the scale of non-performing loans. Park (2012), based on the 2002-2004 year data of more than 70 countries, also found that corruption significantly exacerbated the problem of non-performing loans for commercial banks, and found corruption distorting the investment of commercial bank credit, thus reducing the level of economic growth. Rajeev \& Iftekhar (2011) also found that corruption is positively related to bad debts of commercial banks. However, Li \& Zhang (2014), based on the world bank's system environmental quality survey data on the operation of Chinese enterprises in 2012, uses the Tobit regression method to find that a certain degree of corruption is beneficial to the allocation of bank credit resources, but a higher degree of corruption will inhibit the allocation of bank 
credit resources.

\subsection{Other Factors on Bank Risk}

The impact of monetary policy on commercial banks' risk taking is the most noticeable. Since the 2008 financial crisis, economists have questioned the two mechanisms of the transmission of the classic monetary policy: monetary channels and credit channels, which only consider the lack of monetary policy through monetary supply and bank credit issues to adjust the macro-economy, ignoring the action of commercial banks to respond to monetary policy. Borio \& Zhu (2009) clearly put forward the risk bearing channels of monetary policy banks, and think that monetary policy will affect the risk awareness or risk tolerance of financial institutions, and then change the risk position of financial institutions, that is to say, for monetary policy, commercial banks are not only passive acceptance of change, but can be based on practice. Active strain. Borio \& Zhu (2009), Delis \& Kouretas (2011), Valencia (2014), through the construction of the bank risk bearing model of monetary policy, concluded that a long time loose monetary policy led to the increasing risk of commercial banks, and a significant negative correlation between the monetary policy and the bank risk bearing variables. The empirical study of Delis \& Kouretas (2011) against euro zone banks shows that low interest rates significantly increase the risk preference of commercial banks, but their effects show obvious individual characteristics, and out of statement business accounts for more risk attempts than higher banks. Delis \& Kouretas (2011) also conclude that capital adequacy can affect the extent to which monetary policy plays a role in bank risk bearing, and that commercial banks with high capital adequacy ratio are more capable of counteracting the impact of monetary policy. Bliss \& Kaufman (2013) believe that the impact of monetary policy on the supply of bank credit and the real economy is not symmetrical, and the effect of austerity policy is stronger than that of expansionary policy. Das et al. (2007), Guo (2012), Qiu \& Liu (2011), He, Hong, Wang et al. (2011) found that the growth of GDP was negatively related to the bank's bad loan rate; Tang \& Fang (2011) established a macro pressure test model to study the impact of macroeconomic fluctuations on the credit risk of commercial banks, and found the pressure on the slowdown in GDP growth, CPI increase, and M2 growth. Under the situation, the non-performing loan rate of commercial banks will rise significantly. By analyzing the relationship between economic capital and the economic cycle and the credit cycle, Pan \& Peng (2014) finds that the change of the asset risk of Chinese commercial banks with the GDP growth rate and the credit/GDP fluctuation is not significant.

Hagendorff \& Vallascas (2011) point out that the financial crisis in 2008 was caused by excessive bank executives' pursuit of high pay, which led to excessive bank risk. Based on the data of listed banks in China, Wen (2015) and Xie (2015) found that the bank executives' compensation and risk bear a positive correlation. Among them, Zhang, Lu, \& Sang (2014) divided executive compensation 
into power compensation, incentive pay, and control salary. Only incentive pay was positively related to banking system risk. The risk transmission channel is the mismatch of time limit; Wen (2015) found that the positive correlation between bank executives' compensation and risk bearing will result in the positive adjustment effect in the period of asset value expansion, but the strong demand for lower compensation is formed in the stage of asset value decline.

Goel \& Thakor (2008) and Ulrike \& Geoffrey (2005) think managers are more optimistic and the risk taking level of enterprises is higher. Zhang, Lu, \& Sang (2014) use the panel data of 34 unlisted commercial banks in China for 2000-2011 to find that investor sentiment is negatively related to bank risk, and investor sentiment is negatively correlated with bank managers' optimism. Liang, Yang, \& Jiang (2016) based on the data of 42 banks in China in the past 2004-2013 years, the study found that political connections and financial links could significantly inhibit banks' risk taking.

From the above literatures, we can see that the impact of institutional factors on bank risk has not been paid attention to. Whether the institutional environment affects the bank risk? How the institutional environment affects the bank risk? These questions temporarily lack systematic researches.

\section{Theoretical Model}

This paper uses the endogenous iterative growth model of Mahmoud \& Suliman (2008) system environment and banking system growth relationship. Suppose the production function is the Cobb Douglas production function:

$$
Y_{t}=A_{t} K_{t}^{\alpha} L_{t}^{1-\alpha}
$$

The marginal output of the available capital $K$ is $\alpha$.

Suppose a two dollar society exists only in enterprises and banks. At the time of $T, h$ and the bank signed an interest rate of $r_{t}^{l}$. The loan amount is $d_{t}$ and the time limit is from $t$ to $t+1$. The output of the loan is:

$$
k_{t+1}^{h}=\left(1+\varepsilon_{h}\right) d_{t}
$$

The $\varepsilon_{h}$ is a specific shock of the individual, assuming that its density function is the symmetric function $f\left(\varepsilon_{h}\right)$ of the domain defined on $\left[-\varepsilon_{m}, \varepsilon_{m}\right]$, of which $\varepsilon_{m}<1$ is epsilon. If the enterprise $h$ can return the loan normally, the bank can get the income of $\left(1+r_{t}^{l}\right) d_{t}$; if the enterprise $\mathrm{h}$ default does not return the loan, the bank can obtain $\lambda$ part of the output by legal means, which reflects the rule of law, and according to the actual situation, the surplus $(1-\lambda)$ part if the enterprise passes the irregular channel distribution of the gamma ratio to the most. In the end consumer, this part of the informal income cannot be obtained by the bank, so the compensation that the bank can get is the two parts of lambda $\lambda k_{t+1}^{h}$ and $(1-\gamma)(1-\lambda) k_{t+1}^{h}$. A good system environment, more sound legal system, more effective supervision of the market, the banks in the breach of contract by legal means to profit a greater share ( $\lambda$ grows), the less the regular channel of sales of enterprises ( $\gamma$ declines). If an enterprise chooses to default, its wealth at $t$ 
+1 time is alpha gamma $\alpha \gamma(1-\lambda) k_{t+1}^{h}$, and if it does not default, it is alpha $\alpha\left(k_{t+1}^{h}-\left(1+r_{t}^{l}\right) d_{t}\right)=\alpha\left(\varepsilon_{h}-r_{t}^{l}\right) d_{t}$. If an enterprise chooses to default, then $\alpha \gamma(1-\lambda) k_{t+1}^{h}>\alpha\left(\varepsilon_{h}-r_{t}^{l}\right) d_{t}$ according to the past economic situation and

$$
\varepsilon_{h}<\varepsilon_{t}^{*}=\left[r_{t}^{l}+\gamma(1-\lambda)\right] /[1-\gamma(1-\lambda)]>0
$$

It can also be obtained: $1+r_{t}^{l}=\left(1+\varepsilon_{t}^{*}\right)[1-\gamma(1-\lambda)]$ and epsilon $\varepsilon_{t}^{*}$ are the critical point of breach of contract. It can be seen that the greater the epsilon $\varepsilon_{t}^{*}$, the higher the corresponding loan interest rate, the greater the possibility of default, the greater the risk for commercial banks to undertake.

For a bank, the cost hypothesis is the principal of the loan, that is, $d_{t}=\omega_{t}$, which provides funds to a number of enterprises, including the normal return of the loan and the default of the loan. For the normal return loan, the bank's profit is

$$
\Pi_{b, t+1}=\int_{\varepsilon_{t}^{*}}^{\varepsilon_{m}}\left[\left(1+r_{t}^{l}\right) d_{t}-\left(1+r^{d}\right) \omega_{t}\right] f\left(\varepsilon_{h}\right) \mathrm{d} \varepsilon_{h}
$$

In the case of a breach of contract, the profit of the bank is:

$$
\tilde{\Pi}_{b, t+1}=\int_{-\varepsilon_{m}}^{\varepsilon_{t}^{*}}\left[\lambda k_{t+1}^{h}-\left(1+r^{d}\right) \omega_{t}\right] f\left(\varepsilon_{h}\right) \mathrm{d} \varepsilon_{h}
$$

Combined with the 3.2, 3.4 and 3.5, and other conditions, the bank profit formula is:

$$
\Pi=\Pi_{b, t+1}+\tilde{\Pi}_{b, t+1}=\left(1+r_{t}^{l}\right) \int_{\varepsilon_{t}^{*}}^{\varepsilon_{m}} f\left(\varepsilon_{h}\right) d \varepsilon_{h}+\lambda \int_{-\varepsilon_{m}}^{\varepsilon_{t}^{*}}\left(1+\varepsilon_{h}\right) f\left(\varepsilon_{h}\right) \mathrm{d} \varepsilon_{h}-\left(1+r^{d}\right)
$$

Simplifying the upper form:

$$
\Pi=\left(1+r_{t}^{l}\right) p\left(\varepsilon_{t}^{*}\right)+\lambda\left[1-p\left(\varepsilon_{t}^{*}\right)\right]+\lambda s\left(\varepsilon_{t}^{*}\right)-\left(1+r^{d}\right)
$$

Among $p\left(\varepsilon_{t}^{*}\right)=\int_{\varepsilon_{t}^{*}}^{\varepsilon_{m}} f\left(\varepsilon_{h}\right) \mathrm{d} \varepsilon_{h}, s\left(\varepsilon_{t}^{*}\right)=\int_{-\varepsilon_{m}}^{\varepsilon_{t}^{*}}\left(1+\varepsilon_{h}\right) f\left(\varepsilon_{h}\right) \mathrm{d} \varepsilon_{h}$

If $\beta=1-\gamma(1-\lambda)$, the profit function is decomposed into

$$
\begin{gathered}
g(\varepsilon)=\beta(1+\varepsilon) p(\varepsilon) \\
h(\varepsilon)=1+r^{d}-\lambda[1+s(\varepsilon)-p(\varepsilon)]
\end{gathered}
$$

For $p\left(-\varepsilon_{m}\right)=1, p\left(\varepsilon_{m}\right)=0, s\left(-\varepsilon_{m}\right)=s\left(\varepsilon_{m}\right)=0$, $p^{\prime}(\varepsilon)=\partial p / \partial \varepsilon=-f(\varepsilon)<0, \partial s / \partial \varepsilon=-\varepsilon p^{\prime}(\varepsilon)>0$, The first and two derivative of the above two functions are

$$
\begin{gathered}
g^{\prime}(\varepsilon)=-\beta(1+\varepsilon) f(\varepsilon)+\beta p(\varepsilon) \\
h^{\prime}(\varepsilon)=-\lambda\left[s^{\prime}(\varepsilon)-p^{\prime}(\varepsilon)\right]=-\lambda(1+\varepsilon) f(\varepsilon)<0 \\
g^{\prime \prime}(\varepsilon)=-\beta\left[(1+\varepsilon) f^{\prime}(\varepsilon)+2 f(\varepsilon)\right] \\
h^{\prime \prime}(\varepsilon)=-\lambda\left[(1+\varepsilon) f^{\prime}(\varepsilon)+f(\varepsilon)\right]
\end{gathered}
$$

When a bank is in a perfectly competitive market, its total profit is 0 :

$$
g\left(\varepsilon^{*}\right)=h\left(\varepsilon^{*}\right)
$$




$$
\text { If } \begin{aligned}
& \Delta\left(\varepsilon^{*}\right)=\partial \Pi / \partial \varepsilon^{*}= g^{\prime}\left(\varepsilon^{*}\right)-h^{\prime}\left(\varepsilon^{*}\right), \text { then } \\
& \Delta\left(\varepsilon^{*}\right) \frac{\partial \varepsilon^{*}}{\partial \gamma}=p\left(\varepsilon^{*}\right)\left(1+\varepsilon^{*}\right)(1-\lambda)>0 \\
& \Delta\left(\varepsilon^{*}\right) \frac{\partial \varepsilon^{*}}{\partial \lambda}=\left[1-\gamma\left(1+\varepsilon^{*}\right)\right] p\left(\varepsilon^{*}\right)-1-s\left(\varepsilon^{*}\right)<0
\end{aligned}
$$

If we satisfy the $\Delta\left(\varepsilon^{*}\right)>0$ then $\partial \varepsilon^{*} / \partial \gamma>0, \partial \varepsilon^{*} / \partial \lambda<0$. The unsuccessful ratio is $1-p\left(\varepsilon_{t+1}^{*}\right)=\int_{-\varepsilon_{m}}^{\varepsilon_{t}^{*}} f\left(\varepsilon_{h}\right) \mathrm{d} \varepsilon_{h}$, then the more profits a bank gains through legal means, the less illegal income the enterprise has, the lower the credit risk of bank.

\section{Research Design}

\subsection{Samples and Data Sources}

This paper selects the annual data of 147 Chinese commercial banks in 2002 2016, including 5 state-owned banks, 13 national joint-stock banks, 68 urban commercial banks and 61 rural commercial banks, which are mainly obtained through the Tai'an database of the country and the websites of each bank. From the world bank's world governance index database and the global financial development report, this paper obtains data from social system factors and industry environment respectively, and obtains economic freedom index, trade freedom index and monetary freedom index from the economic freedom index issued by the Heritage Foundation, and other data. Data obtained from the National Bureau of statistics and other websites.

\subsection{Design of Model and Hypothesis}

\subsubsection{Model}

$$
R I S K_{i, t}=\alpha_{0}+\beta_{1} * X_{t}+\sum_{j=1}^{3} \theta_{j} * B C_{i, t}+\mu_{i}+\varepsilon_{i, t}
$$

Among them, RISK is the risk variable, $X$ is the institutional factor, $B C$ is the bank control variable, and $\mu_{i}$ is the individual error item; $\varepsilon_{i, t}$ represents the random error term of the model.

\subsubsection{Hypothesis}

According to the existing theoretical results, this paper will put forward the hypothesis from five aspects:

Suppose H1a: $X_{t}=C O C_{t}, \beta_{1}<0$. There is a negative correlation between corruption control level and bank risk. Wang \& Wang (2016) found that the degree of government corruption is positively related to the scale of non-performing loans. Park (2012) and Rajeev \& Iftekhar (2011) also found that corruption and bad debts are positively correlated. In turn, if the level of corruption control is high, the level of bad debt can be reduced.

Suppose H1b: $X_{t}=G E_{t}, \beta_{1}<0$. The level of government efficiency has a negative impact on bank risk. Li \& Zeng (2016) found that improving the administrative efficiency of government helps to improve the efficiency of banks. This 
paper argues that government efficiency has many effects on bank management, and its improvement will help to mitigate bank risk.

Suppose H1c: $X_{t}=R Q_{t}, \beta_{1}<0$. There is a negative correlation between supervision quality and bank risk. The improvement of regulatory quality can enable the government to better play its role in market regulation, and is more conducive to the implementation of regulatory policies to reduce the risk of commercial banks.

Suppose H1d: $X_{t}=R O L_{t}, \beta_{1}<0$. The level of the rule of law has a negative correlation with the bank risk. Shao (2010) studies found that in areas with high level of rule of law, the level of financial development is higher, the proportion of middle and long term loans is larger, and the risk of bank is smaller than that of the low level of the rule of law.

Suppose H1e: $X_{t}=P O L_{t}, \beta_{1}<0$. There is a negative correlation between political stability index and bank risk. Chan, Koh, Zainir et al. (2015) found that the more stable the political situation, the higher the efficiency of the commercial banks, the stability of a country's political situation is the fundamental development of the economy, and the uncertainty of the banks' operation by the turmoil, the war and the terrorist attacks.

\subsection{Variable Definition}

\subsubsection{Bank's Risk-Taking}

1) Non systematic risk

a) Zscore

$$
\text { Zscore }=(\mathrm{ROA}+\mathrm{CAR}) / \sigma(\mathrm{ROA})
$$

Among them, ROA represents the total return on assets of banks, CAR indicates the capital adequacy ratio of banks, and sigma (ROA) represents the standard deviation of the total assets yield of banks. The $\mathrm{Z}$ index is inversely proportional to the risk of the bank. The smaller the value, the greater the risk.

b) Risk weighted asset ratio (RWAR)

Risk weighted assets $=$ total equity/capital adequacy ratio

RWAR = risk weighted assets/total assets

2) Systematic risk

Long-term marginal expected loss (LRMES)

Zhang, Lu, \& Sang (2014) use LRMES as a risk index to reflect the systemic risk of commercial banks in our country. The following methods can be used to estimate the annual LRMES value. And LRMES 1-EXP $\left(-18^{*} \mathrm{MES}\right)$.

\subsubsection{Influence Factor Variable}

1) The institution factors are measured by the state governance indicators, which originate from the world governance index (WGI) including the level of corruption control (COC), the level of government efficiency (GE), the quality of supervision (RQ), the level of the rule of law (ROL), and the political stability index (POL). The world governance index (WGI) is the original data obtained 
by the world bank according to 32 institutions through questionnaire survey, expert scoring and institutional statistical data. It is aggregated by the unobservable component model into six major indexes, and the valuation range is between $-2.5 \sim 2.5$. The original data of the comprehensive index cover 215 countries, to a certain extent, to avoid subjective one-sided; the model generation index estimates the value of the standard deviation, so that the accuracy of the estimate can be judged. The comprehensive index can be used in transnational or inter temporal comparison. Control of Corruption captures perceptions of the extent to which public power is exercised for private gain, including both petty and grand forms of corruption, as well as "capture" of the state by elites and private interests. Government Effectiveness captures perceptions of the quality of public services, the quality of the civil service and the degree of its independence from political pressures, the quality of policy formulation and implementation, and the credibility of the government's commitment to such policies. Regulatory Quality captures perceptions of the ability of the government to formulate and implement sound policies and regulations that permit and promote private sector development. Rule of Law captures perceptions of the extent to which agents have confidence in and abide by the rules of society, and in particular the quality of contract enforcement, property rights, the police, and the courts, as well as the likelihood of crime and violence. Political Stability and Absence of Violence/Terrorism measures perceptions of the likelihood of political instability and/or politically-motivated violence, including terrorism.

2) Individual characteristics of banks include bank size (lnAsset), profitability (ROA) and non interest income ratio (NIIr). From major databases and company annual reports. The size of the bank. Because of the phenomenon of "big but not falling down", banks with larger scale have more risk diversification and stronger risk taking ability. Profitability. The stronger the banks' profitability is, the lower the risk level is. The proportion of non interest income. With the deepening of the market-oriented reform of the deposit and loan interest rate, the simple traditional credit business cannot meet the needs of the development of the bank. It is necessary to make up more intermediate business or investment bond to make up the income vacancy as a necessary choice for commercial banks. The diversification of income sources may affect the risk degree of the bank.

The description of the above variables is shown in Table 1.

\section{Empirical Analysis}

\subsection{Descriptive Statistics}

Table 2 is a descriptive statistical list of the variables. Because of the common existence of earnings management in commercial banks, the standard deviation of ROA is often low, which leads to the excessive $\mathrm{Z}$ index of risk variables, so the value is adopted. It is known from the table that the individual difference of $\mathrm{Z}$ index is larger, the standard deviation is 1.265 , the minimum value is 1.338 , the maximum is 20.678 . The risk assets share the same fluctuation with RWAR, the 
Table 1. Definition of major variables.

\begin{tabular}{|c|c|c|}
\hline Variable & Name & Description \\
\hline Zscore & $\mathrm{Z}$ index & $\begin{array}{l}(\mathrm{ROA}+\mathrm{CAR}) / \sigma(\mathrm{ROA}), \text { Among them, } \mathrm{CAR} \text { is capital } \\
\text { adequacy ratio and } \mathrm{ROA} \text { is assets return rate. }\end{array}$ \\
\hline RWAR & Risk weighted asset ratio & Risk weighted assets/total assets \\
\hline LRMES & $\begin{array}{l}\text { Long-term marginal expected } \\
\text { loss }\end{array}$ & $\begin{array}{l}\text { Expected loss of equity value of commercial banks during a } \\
\text { period of } 40 \% \text { decline in market returns }\end{array}$ \\
\hline $\mathrm{COC}$ & Level of corruption control & $\begin{array}{l}\text { The government's ability to prevent and crack down on } \\
\text { personal abuse of power }\end{array}$ \\
\hline GE & Government efficiency level & $\begin{array}{l}\text { Government public service, policy making and } \\
\text { implementation level }\end{array}$ \\
\hline RQ & Regulation quality & $\begin{array}{c}\text { The government's effect on the supervision of enterprises } \\
\text { and society }\end{array}$ \\
\hline ROL & The level of the rule of law & The degree of development of a country's legal system \\
\hline POL & Political stability index & Measure the stability of a country's political situation \\
\hline $\ln$ Asset & Bank scale & The value of the bank assets \\
\hline ROA & Profitability & Bank's rate of return on assets \\
\hline NIIr & Non interest income ratio & (total income - interest income)/total income \\
\hline
\end{tabular}

Data source: the world governance index (WGI), the Tai'an database of the country and the websites of each bank.

Table 2. Summary statistics.

\begin{tabular}{cccccc}
\hline VARIABLES & $\mathrm{N}$ & mean & $\mathrm{sd}$ & $\min$ & $\max$ \\
\hline Zscore & 1170 & 4.735 & 1.265 & 1.338 & 20.678 \\
RWAR & 1172 & 0.588 & 0.133 & -0.178 & 0.968 \\
LRMES & 165 & -1.089 & 3.086 & -11.504 & 2.510 \\
COC & 1172 & -0.416 & 0.110 & -0.608 & -0.252 \\
GE & 1172 & 0.171 & 0.151 & -0.119 & 0.408 \\
RQ & 1172 & -0.248 & 0.041 & -0.513 & -0.150 \\
ROL & 1172 & -0.440 & 0.095 & -0.639 & -0.223 \\
POL & 1172 & -0.542 & 0.052 & -0.657 & -0.327 \\
InAsset & 1172 & 11.710 & 1.729 & 7.522 & 16.999 \\
ROA & 1172 & 1.146 & 0.546 & -1.390 & 4.710 \\
NIIr & 1168 & 0.190 & 0.171 & 0.001 & 0.953 \\
\hline
\end{tabular}

mean value is 0.558 , the standard deviation reaches 0.133 , the lowest 0.178 (the South China Sea agricultural firm's capital adequacy ratio is negative RWAR is negative) 0.968 , indicating the banks. The ability to configure risk assets is uneven. The systemic risk LRMES is the use of 16 listed banks (the other two, which are too short to simulate the DCC-GARCH process) in 2005-2016 (the Shanghai and Shenzhen 300 index as the market rate of return set up in 2005), the stock data is calculated (the implementation code is detailed in the appendix). 
The average systemic risk of national commercial banks is at the middle level, the maximum value is 2.510 . Compared with the lowest value -11.504 , it also shows that the overall level of systemic risk of commercial banks in China is not too high. The size of the assets is more volatile, the average value of the logarithm is 11.71 , the standard deviation is 1.729 , the minimum value is 7.522 , the maximum value reaches 16.99. From the extracted samples, the assets of 5 state-owned banks and 13 national banks are found to be far larger than the other 130 local banks, and the local banks account for the total capital. The scale of production is $1 \%$, which is likely to affect the empirical results. Similarly, the proportion of non interest income to business income also varies greatly, from a minimum of 0.001 to the highest of 0.953 (some banks, such as the Bank of Wuhai and the Bank of Shaoxing, have expanded the source of investment gains and intermediate income business in 2016 because of a sharp decline in interest rates).

\subsection{Correlation Analysis}

Table 3 is the correlation statistics of the variables. It can be found that the absolute values of the correlation coefficients between individual variables are larger than that of 0.5:COC and GE, COC and RQ, GE and ROL, etc. in front of the model, taking one by one to examine their impact on the risk; in terms of control variables.

\subsection{Regression Analysis}

The model (1) is used to examine the influence of social institutional factors on the non systematic and systemic risk of the bank from the institutional perspective. The previous hypothesis H1a to H1e is tested. Through the Hausman test, the following regressions all use the fixed effect model. In order to reduce the adverse effect of the heteroscedasticity, robust standard errors are applied in the regression.

Table 4 is the fixed effect regression result of institutional factors on Zindicators of risk indicators. The regression coefficient of government efficiency GE is -1.445 , which is significant at the $1 \%$ confidence level. It shows that the improvement of government service efficiency will increase the bank's bankruptcy risk. It is known from the definition of bankruptcy risk that the improvement of

Table 3. The Pearson correlation for main variables.

\begin{tabular}{cccccccc}
\hline & Zscore & RWAR & LRMES & COC & $G E$ & $R Q$ & $R O L$ \\
\hline Zscore & 1 & & & & & & \\
RWAR & 0.012 & 1 & & & & & \\
LRMES & 0.236 & 0.111 & 1 & & & & \\
COC & 0.087 & 0.319 & 0.126 & 1 & & & \\
$G E$ & -0.088 & 0.239 & -0.233 & 0.620 & 1 & & \\
$R Q$ & -0.123 & -0.299 & -0.403 & -0.772 & -0.359 & 1 & \\
$R O L$ & 0.003 & 0.098 & -0.077 & 0.476 & 0.633 & -0.196 & 1 \\
\hline
\end{tabular}


Table 4. The regression results of the fixed effect of $\mathrm{Z}$ index.

\begin{tabular}{|c|c|c|c|c|c|}
\hline VARIABLES & $\mathrm{H} 1 \mathrm{a}$ & $\mathrm{H} 1 \mathrm{~b}$ & $\mathrm{H} 1 \mathrm{c}$ & H1d & H1e \\
\hline \multirow[t]{2}{*}{$C O C$} & 0.978 & & & & \\
\hline & $(1.62)$ & & & & \\
\hline \multirow[t]{2}{*}{$G E$} & & $-1.445^{\star \star \star}$ & & & \\
\hline & & $(-5.38)$ & & & \\
\hline \multirow[t]{2}{*}{$R Q$} & & & $-4.267^{* * *}$ & & \\
\hline & & & $(-3.49)$ & & \\
\hline \multirow[t]{2}{*}{$R O L$} & & & & -0.120 & \\
\hline & & & & $(-0.28)$ & \\
\hline \multirow[t]{2}{*}{$P O L$} & & & & & 0.838 \\
\hline & & & & & $(1.24)$ \\
\hline \multirow[t]{2}{*}{$R O A$} & $0.454^{\star * *}$ & $0.305^{\star *}$ & $0.429^{* * *}$ & $0.412^{* * *}$ & $0.434^{* * *}$ \\
\hline & $(4.57)$ & $(3.11)$ & $(4.44)$ & $(4.11)$ & $(4.44)$ \\
\hline \multirow[t]{2}{*}{ InAsset } & 0.0517 & $0.355^{\star * *}$ & 0.00147 & $0.193^{* *}$ & $0.192^{* \star *}$ \\
\hline & $(0.52)$ & $(5.67)$ & $(0.02)$ & $(3.13)$ & $(3.48)$ \\
\hline \multirow[t]{2}{*}{ NIIr } & 0.493 & $0.743^{\star *}$ & $0.533^{\star}$ & $0.570^{*}$ & $0.529^{*}$ \\
\hline & $(1.90)$ & $(2.90)$ & $(2.08)$ & $(2.21)$ & $(2.05)$ \\
\hline \multirow[t]{2}{*}{ _cons } & $3.922^{\star *}$ & 0.330 & $3.066^{\star * *}$ & $1.836^{\star}$ & $2.344^{\star *}$ \\
\hline & $(2.88)$ & $(0.47)$ & $(4.28)$ & $(2.25)$ & $(3.29)$ \\
\hline Observations & 1165 & 1165 & 1165 & 1165 & 1165 \\
\hline $\operatorname{Adj} . R 2\left(r 2 \_p\right)$ & 0.0035 & 0.0406 & 0.0019 & 0.0202 & 0.0200 \\
\hline
\end{tabular}

$\mathrm{T}$ values in parentheses, ${ }^{* *},{ }^{* *}$ and ${ }^{*}$ represent statistical significance at the $1 \%, 5 \%$ and $10 \%$, respectively.

government efficiency may effectively promote the competition among banks. The banks face greater competition pressure and the rate of return on assets is more fluctuant. The regression coefficient of regulatory quality RQ is -4.267 , which is significant at the $1 \%$ confidence level. It shows that the supervision quality increases the bank's bankruptcy risk, which indicates that market regulation inhibits the unconventional profit making behavior of commercial banks, reduces the profit level of commercial banks and aggravates the fluctuation of the rate of return on assets. Corruption control level COC, legal level ROL and political stability coefficient POL have no significant effect on $\mathrm{Z}$ indicators. This is not consistent with the conclusions of Wang \& Wang (2016), Park (2012), Rajeev \& Iftekhar (2011) and other scholars. It may be caused by the difference of sample and the different institutional indicators.

In theory, the return of weighted risk assets, which is opposite to the $\mathrm{Z}$ index, is RWAR, and the regression results are shown in Table 5. It can be found that there are differences in the results of the two regression. In addition to the negative government efficiency GE regression coefficient and the $1 \%$ confidence lev$\mathrm{el}$, and the legal level ROL is still not significant, the regression coefficient of the 
Table 5. The regression results of the fixed effect of RWAR.

\begin{tabular}{|c|c|c|c|c|c|}
\hline VARIABLES & H1a & $\mathrm{H} 1 \mathrm{~b}$ & $\mathrm{H} 1 \mathrm{c}$ & H1d & $\mathrm{H} 1 \mathrm{e}$ \\
\hline$C O C$ & $\begin{array}{c}0.479 * * * \\
(10.36)\end{array}$ & & & & \\
\hline$G E$ & & $\begin{array}{c}0.144^{\star * \star} \\
(6.66)\end{array}$ & & & \\
\hline$R Q$ & & & $\begin{array}{c}-0.782^{\star \star \star} \\
(-8.12)\end{array}$ & & \\
\hline$R O L$ & & & & $\begin{array}{l}-0.0261 \\
(-0.75)\end{array}$ & \\
\hline$P O L$ & & & & & $\begin{array}{l}0.112^{\star} \\
(2.05)\end{array}$ \\
\hline$R O A$ & $\begin{array}{c}-0.00372 \\
(-0.49)\end{array}$ & $\begin{array}{c}-0.00913 \\
(-1.16)\end{array}$ & $\begin{array}{c}-0.0189^{\star} \\
(-2.49)\end{array}$ & $\begin{array}{c}-0.0220^{\star *} \\
(-2.72)\end{array}$ & $\begin{array}{c}-0.0185^{\star} \\
(-2.34)\end{array}$ \\
\hline InAsset & $\begin{array}{l}-0.0146 \\
(-1.92)\end{array}$ & $\begin{array}{c}0.0342^{\star * *} \\
(6.80)\end{array}$ & $\begin{array}{c}0.0173^{\star *} \\
(2.89)\end{array}$ & $\begin{array}{c}0.0528^{* * *} \\
(10.56)\end{array}$ & $\begin{array}{c}0.0519^{* * *} \\
(11.66)\end{array}$ \\
\hline NIIr & $\begin{array}{c}-0.0694^{\star * *} \\
(-3.47)\end{array}$ & $\begin{array}{c}-0.0535^{\star *} \\
(-2.61)\end{array}$ & $\begin{array}{c}-0.0410^{*} \\
(-2.03)\end{array}$ & $\begin{array}{l}-0.0342 \\
(-1.64)\end{array}$ & $\begin{array}{l}-0.0403 \\
(-1.93)\end{array}$ \\
\hline _cons & $\begin{array}{c}0.976^{* * *} \\
(9.31)\end{array}$ & $\begin{array}{l}0.184^{* *} \\
(3.23)\end{array}$ & $\begin{array}{c}0.221^{* * *} \\
(3.92)\end{array}$ & $\begin{array}{c}-0.00990 \\
(-0.15)\end{array}$ & $\begin{array}{l}0.0697 \\
(1.21)\end{array}$ \\
\hline Observations & 1166 & 1166 & 1166 & 1166 & 1166 \\
\hline $\operatorname{Adj} . R 2\left(r 2 \_p\right)$ & 0.0930 & 0.0086 & 0.0422 & 0.0372 & 0.0362 \\
\hline
\end{tabular}

$\mathrm{T}$ values in parentheses, ${ }^{* *},{ }^{* *}$ and ${ }^{*}$ represent statistical significance at the $1 \%, 5 \%$ and $10 \%$, respectively.

level of corruption control level COC is 0.479 and the $1 \%$ confidence level is significant, which is also contrary to the original hypothesis, which reveals the enhancement of the national anti-corruption force. As a result, the bank has more risk and high asset allocation due to profit pressure, and the result of the regulatory quality $\mathrm{RQ}$ is different from that of the $\mathrm{Z}$. The market regulation can inhibit the excessive risk investment of commercial banks, the regression coefficient of the political stability coefficient POL is 0.112 , the $10 \%$ confidence level is significant, and the political stability is not consistent with the hypothesis H1e, indicating the stability of the political situation. Promote banks to allocate more high-risk assets under the pressure of profits.

In terms of control variables, the ROA has a significant negative relationship with the bank's bankruptcy risk and the risk asset allocation level. The expansion of the profit income source is always an effective means to control the risk of commercial banks. The increase of operating profit can help the commercial banks to strengthen the ability to resist the risk; the size of the assets to the value of the two kinds of lnAsset The role of risk is opposite, and it has a significant negative relationship with the risk of bankruptcy, and it has a positive relation- 
ship with the level of risk assets allocation. The former reflects the phenomenon of big and no fall, while the latter is more of the big banks engaged in more high risk investment; the non interest income accounts for the NIIr and the bank bankruptcy risk and the risk asset allocation level. In the reverse relationship, non interest income, such as intermediate income, not only enriches the source of the bank's profit, reduces the financial pressure brought by the interest rate market, but also effectively reduces the risk level of the bank.

The regression results of systemic risk LRMES, as shown in Table 6, show that the corruption control level COC, the government efficiency GE, the regulatory quality RQ, the legal level ROL and the political stability coefficient POL are all negative, both of which are significant at the $1 \%$ confidence level, indicating that their improvement reduces the systematic risk water of commercial banks. Flat, exactly consistent with the hypothesis H1a to H1e. Thus, compared with non systemic risks, the improvement of institutional environment has a more positive and more significant effect on systemic risks of commercial banks.

In the control variable, the effect of ROA on systemic risk is not significant, and the regression coefficient is negative. It shows that the good performance of commercial banks still has a positive effect on reducing systemic risk; the return coefficient of the asset scale to the numerical lnAsset is negative, and the role of

Table 6. The regression results of the fixed effect of LRMES.

\begin{tabular}{|c|c|c|c|c|c|}
\hline VARIABLES & H1a & $\mathrm{H} 1 \mathrm{~b}$ & $\mathrm{H} 1 \mathrm{c}$ & H1d & H1e \\
\hline \multirow[t]{2}{*}{$C O C$} & $-15.40^{* * *}$ & & & & \\
\hline & $(-3.73)$ & & & & \\
\hline \multirow[t]{2}{*}{$G E$} & & $-11.68^{* * *}$ & & & \\
\hline & & $(-6.93)$ & & & \\
\hline \multirow[t]{2}{*}{$R Q$} & & & $-43.30^{* * *}$ & & \\
\hline & & & $(-4.29)$ & & \\
\hline \multirow[t]{2}{*}{$R O L$} & & & & $-12.16^{* * *}$ & \\
\hline & & & & $(-4.30)$ & \\
\hline \multirow[t]{2}{*}{$P O L$} & & & & & $-21.59^{* * *}$ \\
\hline & & & & & $(-5.07)$ \\
\hline \multirow[t]{2}{*}{$R O A$} & -1.722 & -1.670 & -1.032 & -1.419 & -1.536 \\
\hline & $(-1.40)$ & $(-1.52)$ & $(-0.87)$ & $(-1.19)$ & $(-1.31)$ \\
\hline \multirow[t]{2}{*}{ InAsset } & $3.913^{\star * *}$ & $2.839^{\star * *}$ & -1.276 & $2.465^{\star * *}$ & $1.105^{\star *}$ \\
\hline & $(5.05)$ & $(7.00)$ & $(-1.75)$ & (5.45) & $(2.94)$ \\
\hline \multirow[t]{2}{*}{ NIIr } & 1.340 & 0.937 & 1.167 & 1.515 & 0.212 \\
\hline & $(0.80)$ & $(0.61)$ & $(0.70)$ & $(0.91)$ & $(0.13)$ \\
\hline \multirow[t]{2}{*}{ _cons } & $-63.65^{* * *}$ & $-39.21^{* * *}$ & 8.265 & $-41.47^{* * *}$ & $-27.30^{* * *}$ \\
\hline & $(-5.04)$ & $(-7.06)$ & $(0.95)$ & $(-5.82)$ & $(-5.10)$ \\
\hline Observations & 164 & 164 & 164 & 164 & 164 \\
\hline $\operatorname{Adj} . R 2\left(r 2 \_p\right)$ & 0.0219 & 0.0814 & 0.0596 & 0.0450 & 0.1345 \\
\hline
\end{tabular}

$\mathrm{T}$ values in parentheses, ${ }^{* * *},{ }^{* *}$ and ${ }^{*}$ represent statistical significance at the $1 \%, 5 \%$ and $10 \%$, respectively. 
the systematic wind insurance is more significant, which is also important to the system. The basic understanding that sex banks must bear more risks is consistent, and the key supervision of large banks is always the focus of the work of various government departments; the non interest income account NIIr has no significant effect on the systemic risk of the bank, indicating that the influence of non interest income is more in the non systemic risk, and to the system. The role of sexual risk is weaker.

Summary: The improvement of government efficiency has increased the non systematic risk of the bank. The quality of the supervision has a positive relationship with the risk of the bank bankruptcy. It has a negative relationship with the level of the allocation of risk assets. The level of corruption control and political stability improve the level of the allocation of risk assets; the improvement of the institutional environment has a stable positive effect on the systemic risk of the bank. Effect.

\subsection{Robusness Examination}

Non systematic risk indicators and systemic risk indicators are expressed by SDROA (volatility of asset reward rate) and CoVaR (Risk Spillover) respectively. The results were Table 7 and Table 8 respectively. Table 7 compared with Table 4

Table 7. The influence of institutional factors on SDROA.

\begin{tabular}{|c|c|c|c|c|c|}
\hline VARIABLES & $\mathrm{H} 1 \mathrm{a}$ & $\mathrm{H} 1 \mathrm{~b}$ & $\mathrm{H} 1 \mathrm{c}$ & H1d & H1e \\
\hline \multirow[t]{2}{*}{ COC } & -0.00551 & & & & \\
\hline & $(-0.06)$ & & & & \\
\hline \multirow[t]{2}{*}{$G E$} & & $0.171^{\star * *}$ & & & \\
\hline & & $(4.31)$ & & & \\
\hline \multirow[t]{2}{*}{$R Q$} & & & -0.136 & & \\
\hline & & & $(-0.76)$ & & \\
\hline \multirow[t]{2}{*}{$R O L$} & & & & -0.0157 & \\
\hline & & & & $(-0.25)$ & \\
\hline \multirow[t]{2}{*}{$P O L$} & & & & & $-0.253^{*}$ \\
\hline & & & & & $(-2.55)$ \\
\hline \multirow[t]{2}{*}{$R O A$} & $-0.060^{* * *}$ & $-0.046^{\star *}$ & $-0.060^{* * *}$ & $-0.061^{\star \star *}$ & $-0.065^{\star * *}$ \\
\hline & $(-4.17)$ & $(-3.25)$ & $(-4.23)$ & $(-4.17)$ & $(-4.55)$ \\
\hline \multirow[t]{2}{*}{ InAsset } & $-0.046^{\star *}$ & $-0.066^{* * *}$ & $-0.052^{* * *}$ & $-0.045^{\star * *}$ & $-0.048^{\star * *}$ \\
\hline & $(-3.17)$ & $(-7.24)$ & $(-4.71)$ & $(-5.05)$ & $(-6.05)$ \\
\hline \multirow[t]{2}{*}{ NIIr } & -0.0721 & $-0.0937^{\star}$ & -0.0734 & -0.0716 & -0.0622 \\
\hline & $(-1.89)$ & $(-2.49)$ & $(-1.95)$ & $(-1.89)$ & $(-1.65)$ \\
\hline \multirow[t]{2}{*}{ _cons } & $0.817^{\star \star \star}$ & $1.022^{* * *}$ & $0.863^{* * *}$ & $0.809^{* * *}$ & $0.716^{* * *}$ \\
\hline & $(4.08)$ & $(9.80)$ & $(8.17)$ & $(6.75)$ & $(6.87)$ \\
\hline Observations & 1166 & 1166 & 1166 & 1166 & 1166 \\
\hline $\operatorname{Adj} . R 2\left(r 2 \_p\right)$ & 0.0331 & 0.0531 & 0.0365 & 0.0326 & 0.0348 \\
\hline
\end{tabular}

$\mathrm{T}$ values in parentheses, ${ }^{* * *},{ }^{* *}$ and ${ }^{*}$ represent statistical significance at the $1 \%, 5 \%$ and $10 \%$, respectively. 
Table 8. The influence of institutional factors on CoVaR.

\begin{tabular}{|c|c|c|c|c|c|}
\hline VARIABLES & $\mathrm{H} 1 \mathrm{a}$ & $\mathrm{H} 1 \mathrm{~b}$ & $\mathrm{H} 1 \mathrm{c}$ & H1d & H1e \\
\hline \multirow[t]{2}{*}{$C O C$} & -0.00551 & & & & \\
\hline & $(-0.06)$ & & & & \\
\hline \multirow[t]{2}{*}{$G E$} & & $0.171^{\star \star \star}$ & & & \\
\hline & & $(4.31)$ & & & \\
\hline \multirow[t]{2}{*}{$R Q$} & & & -0.136 & & \\
\hline & & & $(-0.76)$ & & \\
\hline \multirow[t]{2}{*}{$R O L$} & & & & -0.0157 & \\
\hline & & & & $(-0.25)$ & \\
\hline \multirow[t]{2}{*}{$P O L$} & & & & & $-0.253^{*}$ \\
\hline & & & & & $(-2.55)$ \\
\hline \multirow[t]{2}{*}{$R O A$} & $-0.0605^{* * *}$ & $-0.0468^{* *}$ & $-0.0601^{\star * *}$ & $-0.0613^{* * *}$ & $-0.0650^{* * *}$ \\
\hline & $(-4.17)$ & $(-3.25)$ & $(-4.23)$ & $(-4.17)$ & $(-4.55)$ \\
\hline \multirow[t]{2}{*}{ InAsset } & $-0.0461^{\star *}$ & $-0.0669^{* * *}$ & $-0.0527^{\star * *}$ & $-0.0458^{\star * *}$ & $-0.0488^{\star * *}$ \\
\hline & $(-3.17)$ & $(-7.24)$ & $(-4.71)$ & $(-5.05)$ & $(-6.05)$ \\
\hline \multirow[t]{2}{*}{ NIIr } & -0.0721 & $-0.0937^{\star}$ & -0.0734 & -0.0716 & -0.0622 \\
\hline & $(-1.89)$ & $(-2.49)$ & $(-1.95)$ & $(-1.89)$ & $(-1.65)$ \\
\hline \multirow[t]{2}{*}{ _cons } & $0.817^{* * *}$ & $1.022^{* * *}$ & $0.863^{* * *}$ & $0.809^{* * *}$ & $0.716^{* * *}$ \\
\hline & $(4.08)$ & $(9.80)$ & $(8.17)$ & $(6.75)$ & $(6.87)$ \\
\hline Observations & 1166 & 1166 & 1166 & 1166 & 1166 \\
\hline $\operatorname{Adj} . R 2\left(r 2 \_p\right)$ & 0.1580 & 0.1723 & 0.0233 & 0.2217 & 0.1807 \\
\hline
\end{tabular}

T values in parentheses, ${ }^{* * *},{ }^{* *}$ and ${ }^{*}$ represent statistical significance at the $1 \%, 5 \%$ and $10 \%$, respectively.

and Table 5 showed that the results are stable. Table 8 compared with Table 6 showed that the results are stable.

\section{Research Conclusion}

This paper focuses on the impact of social institutional environment on the risk of commercial banks, and draws the following conclusions.

The improvement of government efficiency has increased the non-systematic risk of the bank. The quality of supervision has a positive relationship with the risk of bank bankruptcy. It has a negative relationship with the level of the allocation of risk assets. The level of corruption control and political stability improve the level of the allocation of risk assets; the improvement of the institutional environment has a positive effect on the stability of the banking system.

In terms of individual characteristics, the ROA of asset returns has a significant negative relationship with the bank's bankruptcy risk and the level of risk asset allocation. The effect of ROA on systemic risk is not significant. The key supervision of the type bank has always been the focus of the work of the government departments of various countries; the non interest income account NIIr 
has no significant effect on the systemic risk of the bank, which indicates that the influence of non interest income is more reflected on the non-systemic risk and is weaker in the systemic risk.

This paper puts forward relevant suggestions for government functional departments and commercial banks. For government departments, despite the many achievements made in the early stage, the improvement of the system is still the top priority such as combating corruption, improving government efficiency, the supervision quality of all sectors of the market, and the level of the rule of law. For commercial banks, they should pay attention to their own risk management and innovate the source of income to cope with the increasingly fierce industry environment. The future researches can involve the impact of institutional factors on the bank behaviors and so on.

\section{References}

Bao, Y., \& Shi, D. L. (2016). Capital Regulation, Deposit Insurance System and Systemic Risk. Financial Problems Research, No. 6, 53-59.

Bliss, R. R., \& Kaufman, G. G. (2003). Bank Procyclicality, Credit Crunches, and Asymmetric Monetary Policy Effects: A Unifying Model. Journal of Applied Finance, 13, No. 2.

Borio, C., \& Zhu, H. (2009). Capital Regulation, Risk-Taking and Monetary Policy: A Missing Link in the Transmission Mechanism? Bis Working Papers, 8, 236-251.

Chan, S. G., Koh, E. H. Y., Zainir, F. et al. (2015). Market Structure, Institutional Framework and Bank Efficiency in ASEAN 5. Journal of Economics \& Business, 82, 84-112. https://doi.org/10.1016/j.jeconbus.2015.07.002

Das, A., Ghosh, S., Vaughan-Williams, L. et al. (2007). Determinants of Credit Risk in Indian State-Owned Banks: An Empirical Investigation. Mpra Paper.

Delis, M. D., \& Kouretas, G. P. (2011). Interest Rates and Bank Risk-Taking. Journal of Banking \& Finance, 35, 840-855. https://doi.org/10.1016/j.jbankfin.2010.09.032

Goel, A. M., \& Thakor, A. V. (2008). Overconfidence, CEO Selection, and Corporate Governance. Journal of Finance, 63, 2737-2784. https://doi.org/10.1111/j.1540-6261.2008.01412.x

Guo, L. L., \& Li, Y. (2014). Monetary Policy, Capital Regulation and Threshold Effect of Commercial Banks' Risk Taking: Theoretical and Empirical Evidence. Southern Economy, 32, 19-35.

Guo, Y. Z. (2012). Study on the Factors Influencing the Decline in Non-Performing Loan Ratio of Commercial Banks. Journal of Shanxi University of Finance and Economics, No. s1, 62-63.

Hagendorff, J., \& Vallascas, F. (2011). CEO Pay Incentives and Risk-Taking: Evidence from Bank Acquisitions. Social Science Electronic Publishing, 17, 1078-1095.

He, C., Hong, H., Wang, Z. W. et al. (2011). Systemic Financial Risk and China's Macro Prudential Management System. Economic Science, 33, 70-80.

Jokipii, T., \& Milne, A. (2011). Bank Capital Buffer and Risk Adjustment Decisions. Journal of Financial Stability, 7, 165-178. https://doi.org/10.1016/j.jfs.2010.02.002

Li, H. J., \& Zhang, Z. Y. (2014). Bribery, Corruption and Bank Credit Resource Allocation: Examining the Role of Formal Institutions. Nanjing Social Sciences, No. 2, 23-32.

Li, L. F., \& Zeng, Y. (2016). The Influence of Institutional Factors on the Efficiency of 
Commercial Banks: Evidence from 106 Chinese Banks. Financial Economics, No. 5, 36-47.

Li, Y., \& Han, L. (2008). Concession Value, Implicit Insurance and Risk Taking-An Empirical Analysis of China's Banking Industry. Financial Research, No. 1, 76-87.

Liang, Y., Yang, Z., \& Jiang, Y. (2016). Bank Executives, Social Connections and Risk Taking of Banks. Modern Finance: Journal of Tianjin University of Finance Economics, No. 6, 80-88.

Mahmoud, S. N., \& Suliman, M. O. (2008). The Institutional Environment and the Banking-Growth Nexus: Theory and Investigation for MENA. MPRA Paper.

Merton, R. C. (1977). An Analytic Derivation of the Cost of Deposit Insurance and Loan Guarantees an Application of Modern Option Pricing Theory. Journal of Banking and Finance, 1, 3-11. https://doi.org/10.1016/0378-4266(77)90015-2

Pan, L., \& Peng, J. (2014). Research on the Mechanism of Countercyclical Capital Raising in China's Banking Industry-Based on the Perspective of Economic Capital Measurement. Financial Economics, No. 4, 13-22.

Park, J. (2012). Corruption, Soundness of the Banking Sector, and Economic Growth: A Cross-Country Study. Journal of International Money \& Finance, 31, 907-929. https://doi.org/10.1016/j.jimonfin.2011.07.007

Qiu, Z., \& Liu, Y. (2011). Research on the Relationship between Credit Risk and Macroeconomic Factors of China Commercial Bank-Based on the Empirical Test of 2000-2009 Year Panel Data. Financial Economics Research, 26, 38-44.

Rajeev, K. G., \& Iftekhar, H. (2011). Economy-Wide Corruption and Bad Loans in Banking: International Evidence. Applied Financial Economics, 21, 455-461. https://doi.org/10.1080/09603107.2010.532112

Shao, M. (2010). Rule of Law, Financial Development and Long Term Bank Loans. World Economic Digest, No. 2, 56-68.

Shim, J. (2010). Capital-Based Regulation, Portfolio Risk and Capital Determination: Empirical Evidence from the US Property-Liability Insurers. Journal of Banking \& Finance, 34, 2450-2461. https://doi.org/10.1016/j.jbankfin.2010.04.003

Tang, T., \& Fang, Z. (2011). Credit Risk and Macro Economy of Commercial Banks: A Study Based on Stress Testing. Contemporary Economic Science, No. 4, 66-71.

Ulrike, M., \& Geoffrey, T. (2005). CEO Overconfidence and Corporate Investment. The Journal of Finance, 60, 2661-2700. https://doi.org/10.1111/j.1540-6261.2005.00813.x

Valencia, F. (2014). Monetary Policy, Bank Leverage, and Financial Stability. Journal of Economic Dynamics \& Control, 47, 20-38. https://doi.org/10.1016/j.jedc.2014.07.010

Wang, X., \& Wang, K. (2016). The Impact of Corruption on Banks' Non-Performing Loans-Based on China's Provincial Dynamic Panel Data GMM Method. Financial Bush: Journal of Zhejiang University of Finance and Economics, No. 8, 36-43.

Wen, B. (2015). Banking Sector Compensation and the Stability of the Economic and Financial System: Sino-US Comparison-SFC Based Research under the Impact of Asset Value Fluctuations. International Financial Research, No. 11, 47-57.

Xie, S. (2015). The Study of the Impact of Corporate Governance on the Risk Bearing of Commercial Banks-Based on the Empirical Analysis of Listed Banks in China. Finance and Economy, No. 8, 75-79.

Zhang, C., Lu, M., \& Sang, X. (2014). Investor Sentiment, Bank Manager Optimism and Risk Taking. Journal of Shanxi University of Finance and Economics, 36, 48-57.

Zhang, J., \& Sun, Y. (2016). An Empirical Study on the Impact of Deposit Insurance System on Bank Risk taking. Economics and Management, 30, 36-45. 